\title{
Estimated Water Withdrawals and Use in New Hampshire, 1995
}

By Laura Medalie

Water-Resources Investigations Report 97-4177

Pembroke, New Hampshire 


\title{
U.S. DEPARTMENT OF THE INTERIOR BRUCE BABBITT, Secretary
}

\author{
U.S. GEOLOGICAL SURVEY \\ Gordon P. Eaton, Director
}

For additional information write to:

Copies of this report can be purchased from:

District Chief

U.S. Geological Survey

New Hampshire/Vermont District

361 Commerce Way

Pembroke, NH 03275
U.S. Geological Survey

Branch of Information Services

Box 25286

Federal Center

Denver, CO 80225 


\section{CONTENTS}

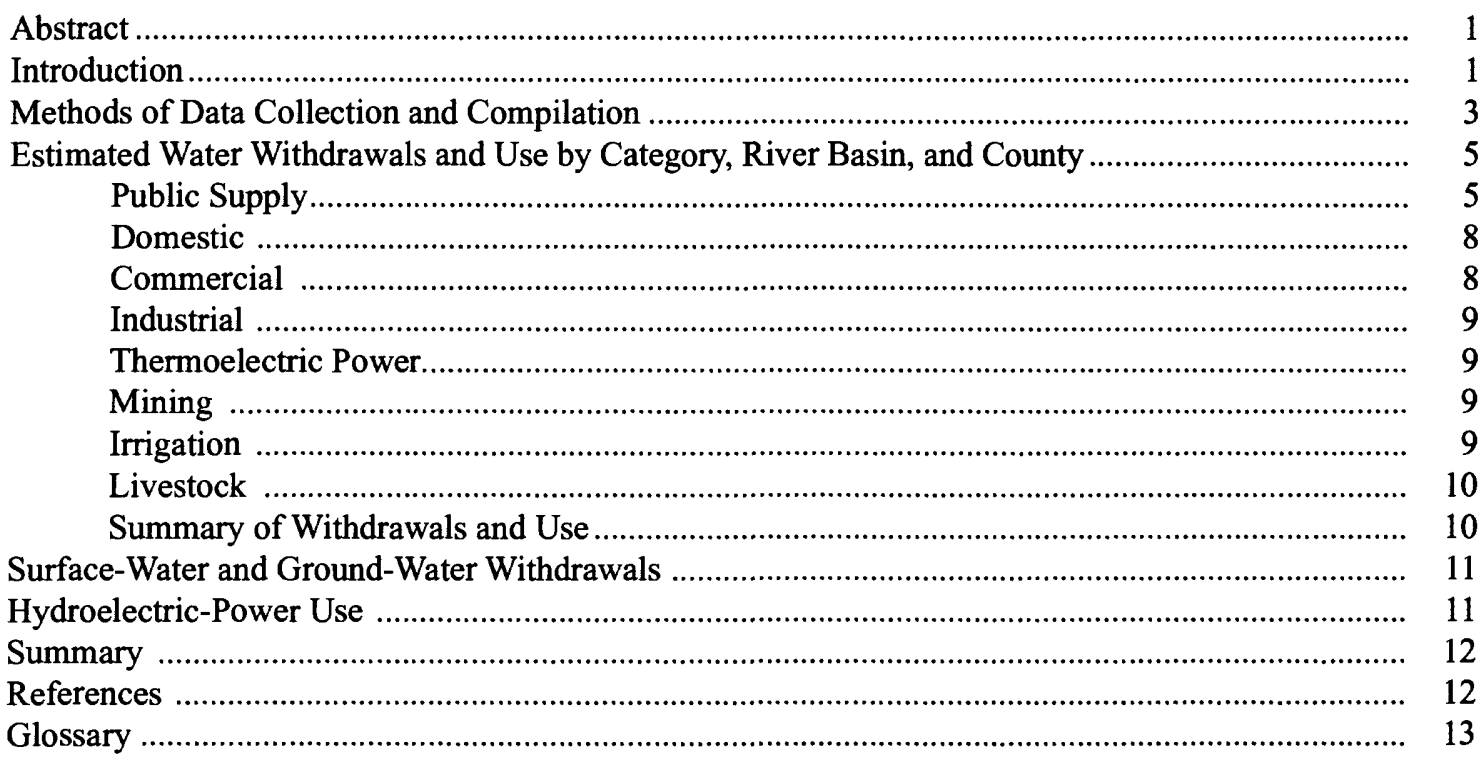

\section{Figures}

1. Map showing the location of major river basins and counties in New Hampshire.

2.-7.Charts showing

2a-h. water withdrawals in New Hampshire, by category of use, for river basins, $1995 \ldots \ldots \ldots \ldots \ldots . .6$

3a-h. water withdrawals in New Hampshire, by category of use, for counties, 1995 .................. 7

4. seasonal commercial water withdrawals in New Hampshire, 1995. ...................................... 8

5. total surface-water and ground-water withdrawals in New Hampshire by (a) river basin

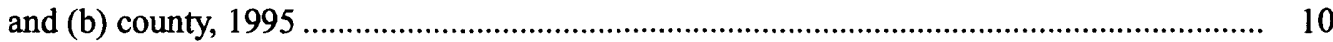

6. percentage of total water use in New Hampshire, by category of use, 1995 .......................... 11

7. surface- and ground-water withdrawals in New Hampshire, by category of use, $1995 \ldots \ldots \ldots \ldots . .12$

\section{Tables}

1. Population and total per capita water use in New Hampshire, by river basins and counties, 1995

2. Public-supplied deliveries, withdrawals, and hydroelectric-power instream use by river basin and county in New Hampshire, 1995

\begin{tabular}{rll}
\hline Multiply & By & To Obtain \\
\hline square mile $\left(\mathrm{mi}^{2}\right)$ & 2.590 & square kilometer \\
gallon per day $(\mathrm{gal} / \mathrm{d})$ & 0.003785 & cubic meter per day \\
cubic meter per day
\end{tabular}





\title{
Estimated Water Withdrawals and Use in New Hampshire, 1995
}

\author{
by Laura Medalie
}

\begin{abstract}
Data on water withdrawals and use in New Hampshire in 1995 were compiled by major river basin and county as part of a nationwide effort by the U.S. Geological Survey to describe water use in the United States by major water-use categories. Withdrawals in the State totaled $450 \mathrm{Mgal} / \mathrm{d}$ (million gallons per day). The largest withdrawals were for thermoelectric power (230 Mgal/d), public supply (98 Mgal/d), and industrial (43 Mgal/d) uses. Other water-use categories included domestic, mining, irrigation, livestock, and hydroelectricpower use. River basins with the largest withdrawals were the Merrimack (320 Mgal/d) and the Upper Androscoggin (37 Mgal/d). Concurrently, the largest withdrawals were in Merrimack (250 $\mathrm{Mgal} / \mathrm{d}$ ) and Hillsborough (59 Mgal/d) Counties. Surface-water withdrawals accounted for about 82 percent of total withdrawals and ground-water withdrawals accounted for the remaining 18 percent. Public-supply withdrawals were distributed to various water users, including domestic, commercial, industrial, and thermoelectric-power users. The largest uses of water, including self-supplied withdrawals and public-supplied deliveries, were for thermoelectric power (230 Mgal/d), domestic (89 Mgal/d), and industrial (56 Mgal/d) uses.
\end{abstract}

\section{INTRODUCTION}

Reliable data on water use provide an important tool for water-resources managers and water-supply planners as they strive to ensure that water supplies are adequate to meet demands. These managers and planners analyze water-use data in combination with climatological, hydrological, and demographic data to forecast future water needs and to resolve cases of conflicting demands, such as between withdrawals and instream uses of water. As part of the U.S. Geological Survey (USGS) National Water-Use Information Program, each State compiles data on significant types of water use every 5 years. Selected data from the 1995 water-use compilation for New Hampshire are presented in this report. The purpose of this report is to provide estimates of water-withdrawal and -use data to water-resources professionals and the general public, to compare data among river basins and counties in New Hampshire, and to present a brief discussion about how the data were derived.

Water-use data were compiled by major river basin and by county. The location of these aggregational units is shown in figure 1 and is intended to be used in conjunction with table 1 . River basins and their codes (8-digit hydrologic cataloging unit code) are delineated by the USGS in cooperation with the U.S. Water Resources Council (Seaber and others, 1987). Although there are some large withdrawals of saline water at the seacoast, this report only includes freshwater withdrawals and use.

Withdrawal and water-use values (unless otherwise indicated) represent estimated average daily 


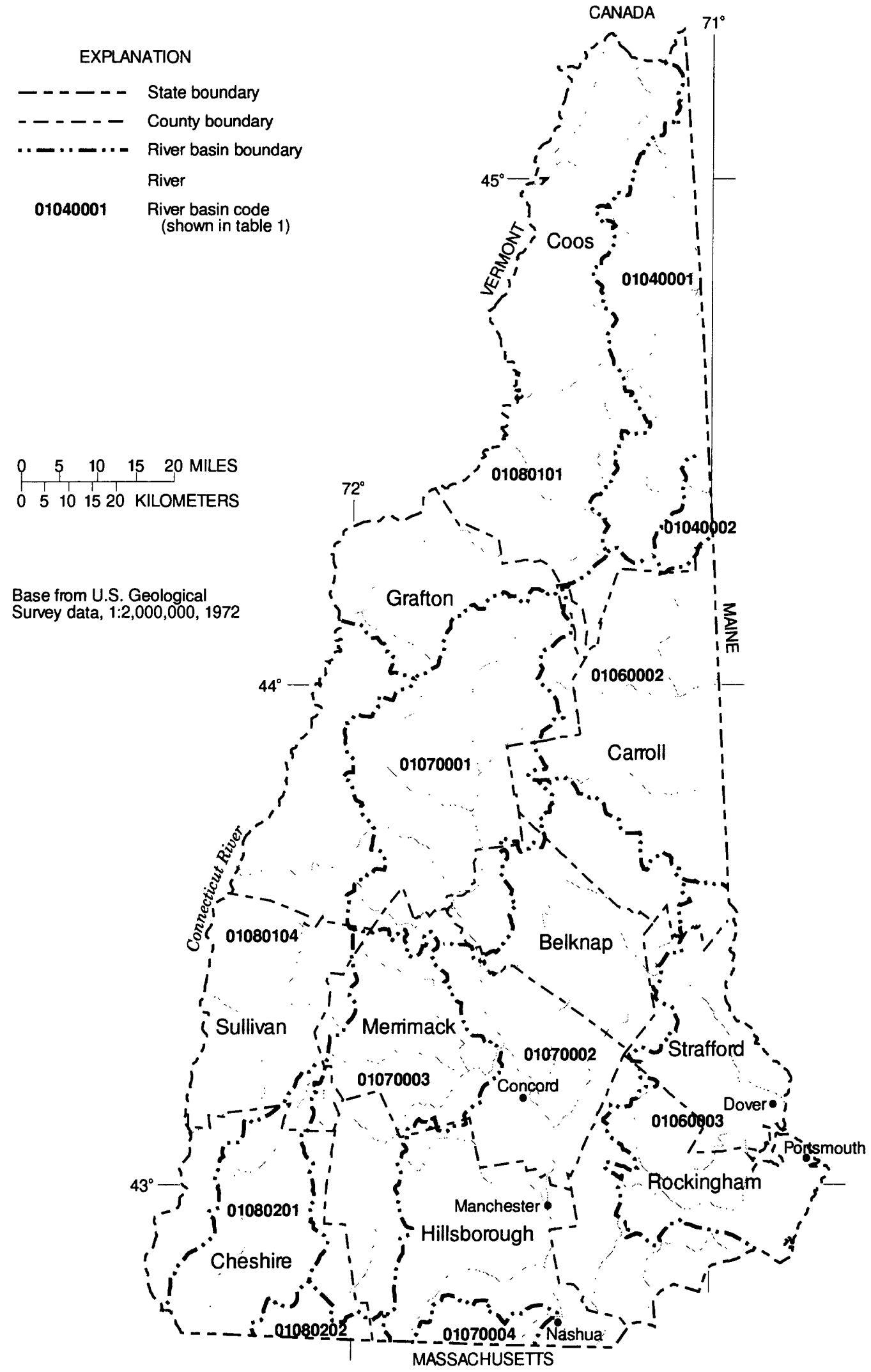

Figure 1. Locations of major river basins and counties in New Hampshire. 
Table 1. Population and total per capita water use in New Hampshire, by river basins and counties, 1995

[Area includes only the part of each river basin that is contained within the borders of New Hampshire. $\mathrm{mi}^{2}$, square mile; gal/d, gallons per day]

\begin{tabular}{|c|c|c|c|c|c|}
\hline $\begin{array}{c}\text { River basin } \\
\text { code } \\
\text { (figure 1) }\end{array}$ & River basin or county name & $\begin{array}{l}\text { Area } \\
\left(\mathrm{mi}^{2}\right)\end{array}$ & $\begin{array}{l}\text { Population } \\
\text { (thousands) }\end{array}$ & $\begin{array}{l}\text { Population with } \\
\text { public supply } \\
\text { (thousands) }\end{array}$ & $\begin{array}{c}\text { Total per } \\
\text { capita water } \\
\text { use (gal/d) }\end{array}$ \\
\hline \multicolumn{6}{|c|}{ River Basins } \\
\hline $\begin{array}{l}01040001 \\
01040002\end{array}$ & $\begin{array}{l}\text { Upper Androscoggin } \\
\text { Lower Androscoggin }\end{array}$ & $\begin{array}{r}696 \\
82\end{array}$ & $\begin{array}{r}13.1 \\
0.4\end{array}$ & $\begin{array}{l}9.8 \\
0\end{array}$ & $\begin{array}{r}2,750 \\
75\end{array}$ \\
\hline 01060002 & Saco & 936 & 24.2 & 10.4 & 219 \\
\hline 01060003 & Piscataqua-Salmon Falls & 893 & 239.7 & 150.0 & 116 \\
\hline 01070001 & Pemigewasset & 1,077 & 34.4 & 13.1 & 252 \\
\hline 01070002 & Merrimack & 2,094 & 548.0 & 342.6 & 562 \\
\hline 01070003 & Contoocook & 823 & 55.3 & 23.4 & 139 \\
\hline 01070004 & Nashua & 95 & 58.2 & 45.4 & 64 \\
\hline 01080101 & Upper Connecticut & 1,575 & 34.5 & 19.7 & 306 \\
\hline 01080104 & Upper Connecticut-Mascoma & 1,167 & 88.2 & 51.5 & 153 \\
\hline 01080201 & Middle Connecticut & 457 & 46.4 & 30.3 & 116 \\
\hline 01080202 & Miller & 85 & 5.9 & 0.8 & 105 \\
\hline & Total & 9,980 & $1,148.3$ & 697.0 & 372 \\
\hline \multicolumn{6}{|c|}{ Counties } \\
\hline & Belknap & 498 & 50.9 & 25.0 & 130 \\
\hline & Carroll & 1,090 & 37.6 & 15.8 & 188 \\
\hline & Cheshire & 792 & 71.2 & 38.7 & 118 \\
\hline & Coos & 1,995 & 33.6 & 21.5 & 1,320 \\
\hline & Grafton & 1,851 & 77.7 & 43.1 & 208 \\
\hline & Hillsborough & 961 & 349.6 & 256.4 & 137 \\
\hline & Merrimack & 1,023 & 123.3 & 75.7 & 1,980 \\
\hline & Rockingham & 773 & 257.6 & 123.5 & 112 \\
\hline & Strafford & 410 & 107.3 & 72.9 & 163 \\
\hline & Sullivan & 587 & 39.5 & 24.4 & 151 \\
\hline & Total & 9,980 & $1,148.3$ & 697.0 & 372 \\
\hline
\end{tabular}

use in 1995 and were derived by dividing estimated total annual withdrawals or use by 365 days. Although this derivation procedure may affect the values for use categories that operate seasonally, such as commercial (which includes snowmaking at ski areas) or irrigation, all use categories are reported to a common baseline, thus providing an overall picture of water use in the State. Because seasonal variations are significant for many commercial users, however, a brief seasonalwithdrawal synopsis is presented in the section on commercial withdrawals and use.

\section{METHODS OF DATA COLLECTION AND COMPILATION}

A combination of site-specific and estimated data was used for many of the water-use categories. Most of the site-specific data that were included with this compilation were collected by the New Hampshire Department of Environmental Services as part of their Water User Registration Program. Since 1987, this program has required quarterly water-use reporting of monthly data to the State for entities using 20,000 gal/d or greater for 7 consecutive days over a 30-day period. Registered water users included 156 public suppliers, 
Table 2. Public-supplied deliveries, withdrawals, and hydroelectric-power instream use by river basin and county in New Hampshire, 1995

[Units are in million gallons per day (Mgal/d); numbers are rounded to the nearest $0.1 \mathrm{Mgal} / \mathrm{d}$ or to two significant figures; values may not add to totals because of independent rounding. Total public-supplied deliveries to thermoelectric-power users was $0.3 \mathrm{Mgal} / \mathrm{d}$.]

\begin{tabular}{|c|c|c|c|c|c|c|c|c|c|c|c|c|c|}
\hline \multirow[b]{2}{*}{$\begin{array}{c}\text { River basin } \\
\text { or county name }\end{array}$} & \multicolumn{3}{|c|}{ Public-supplied deliveries } & \multirow[b]{2}{*}{$\begin{array}{c}\text { Public } \\
\text { supply } \\
\text { with- } \\
\text { drawals }\end{array}$} & \multicolumn{7}{|c|}{ Self-supplied withdrawals } & \multirow[b]{2}{*}{$\begin{array}{c}\text { Total } \\
\text { with- } \\
\text { drawals }\end{array}$} & \multirow{2}{*}{$\begin{array}{c}\text { Hydro- } \\
\text { electric- } \\
\text { power } \\
\text { instream } \\
\text { use } \\
\end{array}$} \\
\hline & $\begin{array}{l}\text { Dom- } \\
\text { estic }\end{array}$ & $\begin{array}{l}\text { Com- } \\
\text { mercial }\end{array}$ & $\begin{array}{l}\text { Indus- } \\
\text { trial }\end{array}$ & & $\begin{array}{l}\text { Dom- } \\
\text { estic }\end{array}$ & $\begin{array}{c}\text { Com- } \\
\text { mercial }\end{array}$ & $\begin{array}{c}\text { Indus- } \\
\text { trial }\end{array}$ & $\begin{array}{l}\text { Thermo- } \\
\text { electric } \\
\text { power }\end{array}$ & Mining & $\begin{array}{l}\text { Irriga- } \\
\text { tion }\end{array}$ & $\begin{array}{l}\text { Live- } \\
\text { stock }\end{array}$ & & \\
\hline \multicolumn{14}{|c|}{ River Basins } \\
\hline Upper Androscoggin & 0.8 & 0.4 & 0.9 & 2.9 & 0.2 & 4.3 & 29 & 0.0 & 0.1 & 0.0 & 0.0 & 37 & 10,000 \\
\hline Lower Androscoggin & .0 & .0 & .0 & .0 & .0 & .0 & .0 & .0 & .0 & .0 & .0 & .0 & .0 \\
\hline Saco & .9 & .4 & .0 & 2.5 & 1.0 & 2.0 & .1 & .3 & .6 & .3 & .0 & 6.8 & 12 \\
\hline $\begin{array}{l}\text { Piscataqua-Salmon } \\
\text { Falls }\end{array}$ & 12 & 4.6 & 2.4 & 18 & 6.3 & 1.8 & 1.0 & .0 & 1.2 & 1.0 & .1 & 29 & 1,200 \\
\hline Pemigewasset & 1.1 & .4 & .2 & 2.1 & 1.5 & 4.5 & .3 & .2 & .1 & .2 & .1 & 9.0 & 1,000 \\
\hline Merrimack & 28 & 11 & 7.2 & 53 & 15 & 14 & 4.2 & 230 & 3.3 & 2.9 & .2 & 320 & 4,400 \\
\hline Contoocook & 1.9 & .6 & .4 & 4.1 & 2.2 & .6 & .9 & .5 & .2 & .7 & .1 & 9.4 & 2,300 \\
\hline Nashua & 3.7 & .0 & .0 & .0 & 0.9 & .1 & .1 & .0 & .1 & .0 & .0 & 1.2 & 550 \\
\hline Upper Connecticut & 1.6 & .5 & .3 & 4.2 & 1.0 & .9 & 5.4 & .4 & .2 & .5 & .1 & 13 & 5,900 \\
\hline $\begin{array}{l}\text { Upper Connecticut- } \\
\text { Mascoma }\end{array}$ & 4.2 & 1.6 & .9 & 7.5 & 2.6 & 1.3 & 1.9 & .3 & .9 & .4 & .1 & 15 & 6,700 \\
\hline Middle Connecticut & 2.5 & 1.0 & .3 & 3.4 & 1.1 & .2 & .2 & .0 & .3 & .2 &. $\mathrm{I}$ & 5.5 & 120 \\
\hline Miller & .1 & .0 & .0 & .1 & .4 & .1 & .0 & .0 & .0 & .0 & .0 & .6 & 570 \\
\hline Total & 57 & 21 & 13 & 98 & 32 & 30 & 43 & 230 & 7.0 & 6.3 & .8 & 450 & 33,000 \\
\hline \multicolumn{14}{|c|}{ Counties } \\
\hline Belknap & 2.1 & 0.9 & 0.3 & 2.9 & 1.8 & 0.8 & 0.4 & 0.0 & 0.3 & 0.4 & 0.0 & 6.7 & 750 \\
\hline Carroll & 1.3 & .6 & .1 & 2.7 & 1.5 & 2.2 & .1 & .3 & .7 & 6 & .0 & 8.1 & 240 \\
\hline Cheshire & 3.2 & 1.2 & .4 & 4.9 & 2.3 & .5 & .4 & .0 & .5 & .4 & .1 & 9.2 & 700 \\
\hline $\operatorname{Coos}$ & 1.8 & .7 & 1.1 & 5.1 & .8 & 4.9 & 34 & .2 & .3 & .3 & .1 & 46 & 11,000 \\
\hline Grafton & 3.5 & 1.6 & .5 & 8.1 & 2.4 & 5.6 & 1.5 & .4 & .6 & .5 & .2 & 19 & 5,800 \\
\hline Hillsborough & 21 & 6.2 & 5.7 & 40 & 6.7 & 5.9 & 3.7 & .0 & 1.3 & 1.8 & .1 & 59 & 2,500 \\
\hline Merrimack & 6.2 & 3.3 & .8 & 9.9 & 3.6 & .8 & .5 & 230 & 1.4 & .8 & .1 & 250 & 4,400 \\
\hline Rockingham & 10 & 4.0 & 2.0 & 9.8 & 8.9 & 2.8 & .8 & .0 & 1.1 & 1.0 & .1 & 24 & .0 \\
\hline Strafford & 6.0 & 1.8 & 1.2 & 12 & 2.5 & 5.9 & .6 & .0 & .4 & .3 & .0 & 22 & 1,100 \\
\hline Sullivan & 2.0 & .5 & .6 & 2.5 & 1.1 & .6 & .7 & .3 & .3 & .2 & .1 & 5.6 & 6,600 \\
\hline Total & 57 & 21 & 13 & 98 & 32 & 30 & 43 & 230 & 7.0 & 6.3 & .8 & 450 & 33,000 \\
\hline
\end{tabular}

44 commercial users (including fish hatcheries, ski areas, and bottlers), 113 industrial facilities, 16 thermoelectric-power facilities (fossil-fuel or nuclear power), 33 mines, 58 irrigation users (crop farms, sod farms, and golf courses), and 101 hydroelectric-power facilities (F.H. Chormann, N.H. Department of Environmental Services, written commun., 1996). Additional site-specific data were collected as part of the U.S. Environmental Protection Agency's Merrimack River Initiative, "Water Use Data Verification Project" (F.H. Chormann, written commun., 1996). Large-volume water users were interviewed by telephone when water-withdrawal data were unavailable through State sources. In this report, the term "site-specific data" refers to data obtained through any of the channels described in this paragraph.

For most water-use categories, estimated data were used to supplement site-specific data. The technique of estimating water-use data differed depending on the category of use. Corroborative data were used when available. In general, a water-use coefficient was developed for each category that related water use to an 
easily obtainable variable specific to that category. These water-use coefficients were derived either from site-specific data compiled during this project or from a related study and were used to estimate the volume of water used by facilities for cases where site-specific data were not available.

For example, site-specific data were used to develop a per capita public-supply delivery coefficient of $82 \mathrm{gal} / \mathrm{d}$ to domestic users. Thus, public-supply withdrawals presented in this report are the sum of sitespecific withdrawals reported to the Water User Registration Program and, for public-supply systems that did not report withdrawals to the State, withdrawals as estimated by multiplying 82 times the population served. Domestic self-supplied per capita water use was estimated as $70 \mathrm{gal} / \mathrm{d}$ (Davis and others, 1991). For commercial and industrial water use, water-use coefficients developed by the U.S. Army Corps of Engineers (Davis and others, 1991) were used to relate water use to the number of employees, for different types of industries or commercial facilities. These estimated data were added to known site-specific data for the commercial and industrial categories.

For the thermoelectric-power category, coefficients relating to power production were developed that were specific to the cooling system design in the power facility. Similarly, for the mining category, water-use coefficients relating to the number of employees were developed that were specific to the type of mining operation. Water for crop irrigation by county was estimated as the difference between the volume of precipitation needed during a typical growing season (May-September) for the irrigated acreage (U.S. Department of Commerce, 1994) and an average county-wide recorded volume of precipitation. For livestock and horses, the number of animals by county (U.S. Department of Commerce, 1994) were multiplied by an animal-specific, water-use coefficient (T. E. Buob, Grafton County Cooperative Extension, oral commun., 1996). For ten hydroelectric facilities without site-specific data from the State Water-User Registration Program, instream-water use was estimated from an equation relating flow to power production (based on the standard power equation).

Compared to a 1990 water-use map report (Medalie and Horn, 1994) that also was produced under the USGS National Water-Use Information Program, more site-specific data were used in 1995 and many of the estimation methods were further developed. Thus, some of the differences between the two data sets do not reflect actual trends in water use.

\section{ESTIMATED WATER WITHDRAWALS AND USE BY CATEGORY, RIVER BASIN, AND COUNTY}

Some water users in each of the categories of this section withdraw surface water or ground water from an on-site supply - they are "self supplied" for their water needs. In addition, some domestic, commercial, industrial, and thermoelectric-power water users receive deliveries from public suppliers. Thus, total water use for these categories is the sum of self-supplied withdrawals and public-supplied deliveries. Water use for the remaining categories - mining, livestock, and irrigation-is assumed to be completely from selfsupplied withdrawals.

\section{Public Supply}

Public-supply withdrawals totaled $98 \mathrm{Mgal} / \mathrm{d}$ (table 2) and accounted for 22 percent of all withdrawals in New Hampshire. Public-supply withdrawals in 1995 increased $1.4 \mathrm{Mgal} / \mathrm{d}$ from the 1990 estimate (95.3 Mgal/d). The largest public-supply withdrawals in New Hampshire were in the Merrimack River Basin (fig. 2a) and Hillsborough County (fig. 3a). The largest water suppliers in the Merrimack River Basin withdraw primarily from surface water and include Manchester Water Works, Pennichuck Water Works (Nashua), and Concord Water Department. The Piscataqua-Salmon Falls River Basin, including the Portsmouth and Dover Water Departments, had the second largest withdrawals for public supply.

Public-supply withdrawals do not equal deliveries to domestic, commercial, industrial, and thermoelectric-power users. Some proportion of the withdrawn water is "unaccounted for", as the result of leaks from pipes, nonmetering (for instance for public uses including municipal buildings or fire fighting), poorly calibrated meters or errors, or transfers into or out of the river basin. Unaccounted-for water can be estimated for each river basin or county by subtracting the sum of the columns labeled "public-supplied deliveries" from "public-supply withdrawals" in table 2. A resulting negative value indicates imports of public-supply water from another river basin or county. 

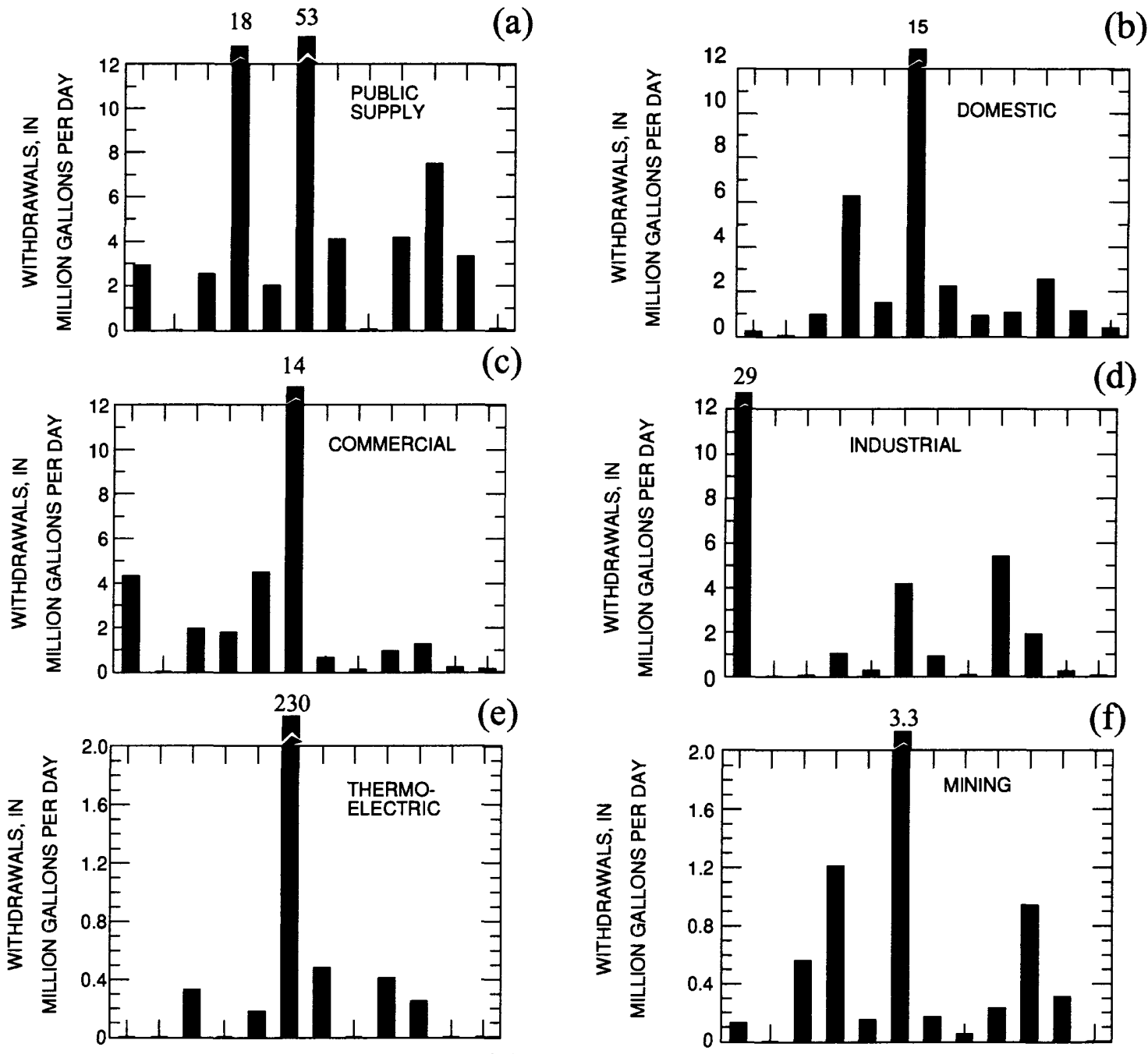

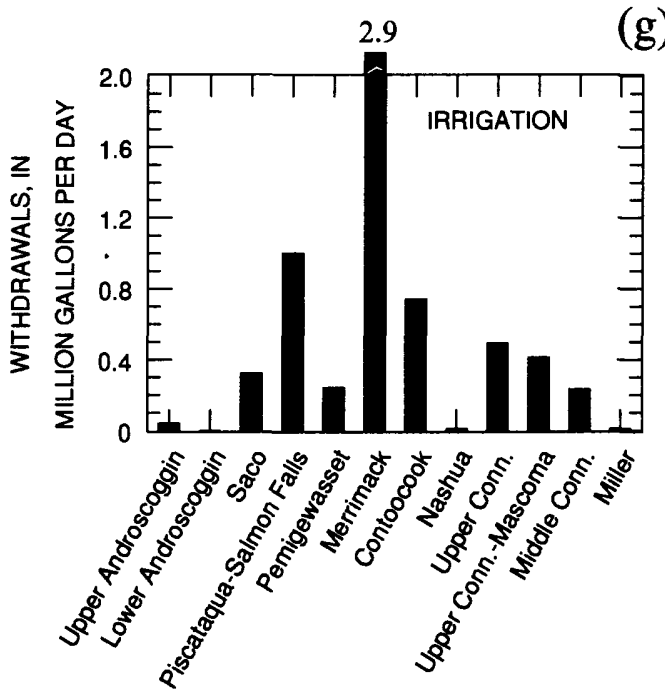

RIVER BASIN $(\mathrm{g})$

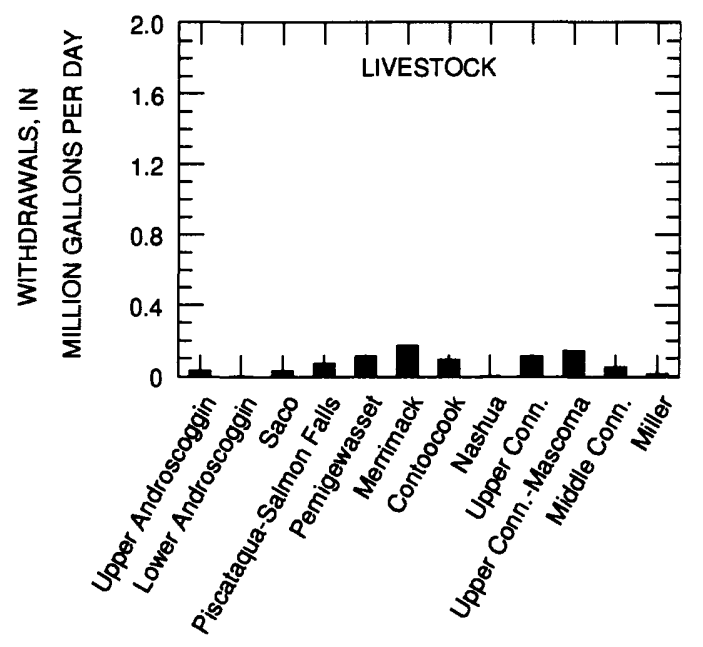

RIVER BASIN

Figure 2. Water withdrawals in New Hampshire by category of use for river basins, 1995.

[Note that the vertical scales are different for the upper four compared to the lower four charts; Conn., Connecticut] 


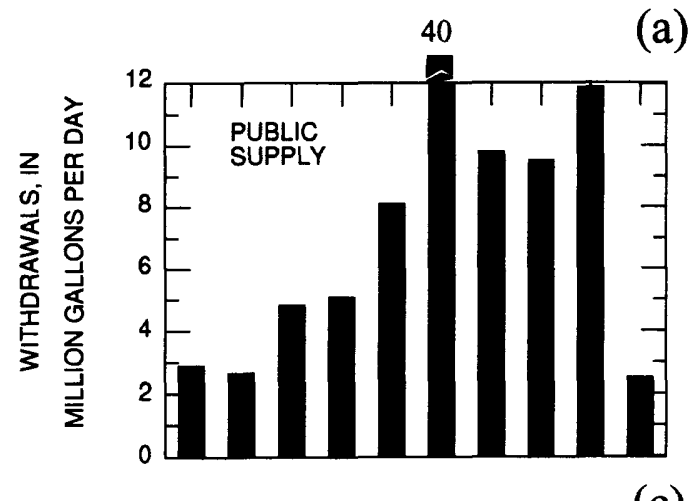

(a)

(b)

(c)
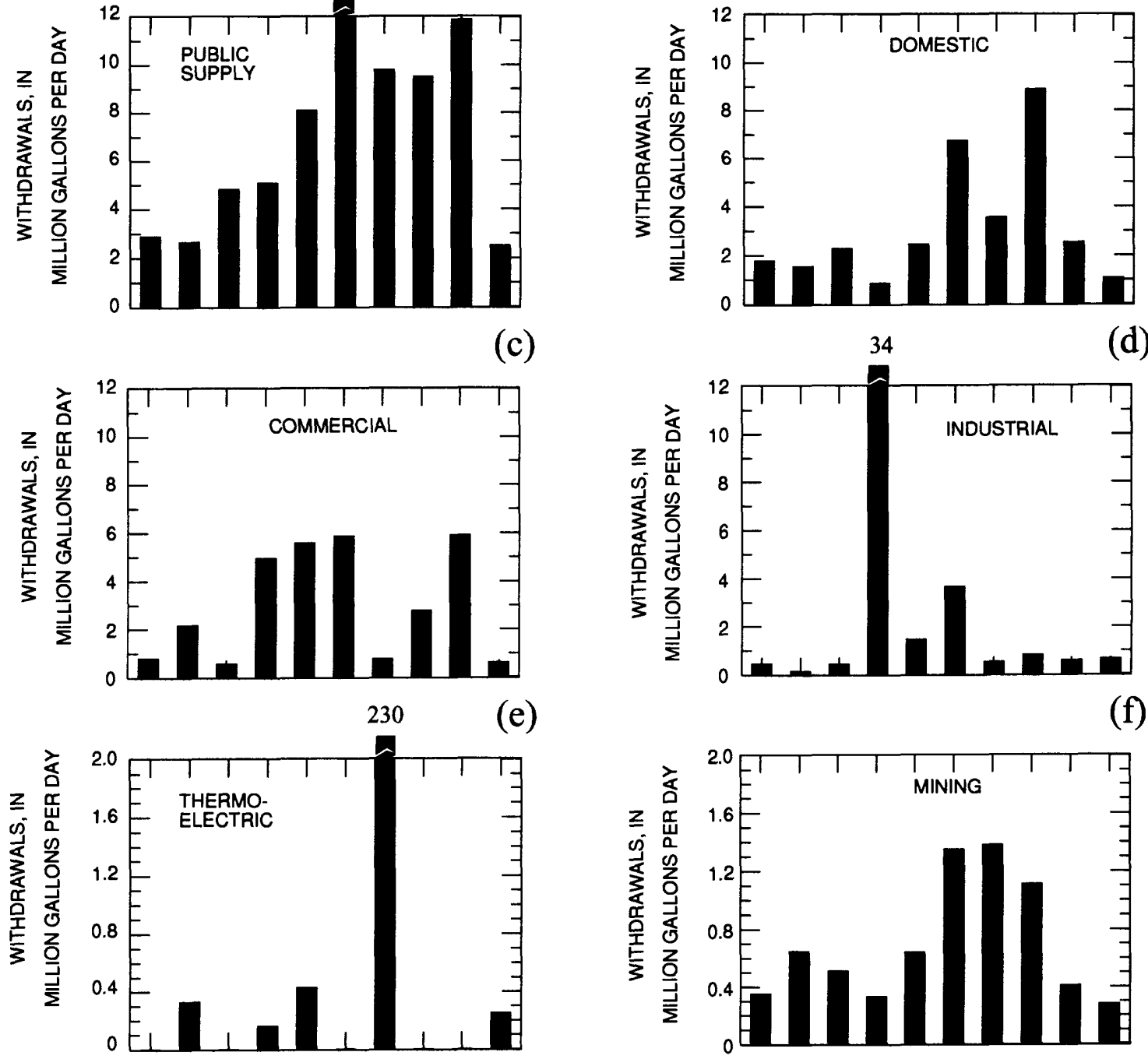

(g)

(h)

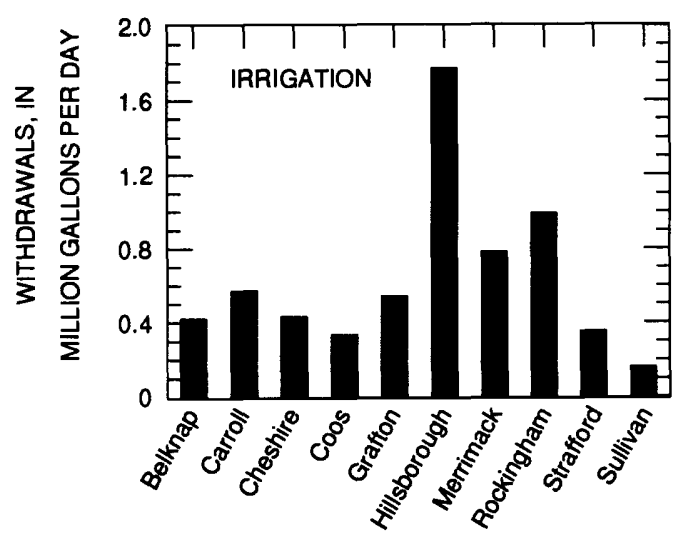

COUNTY

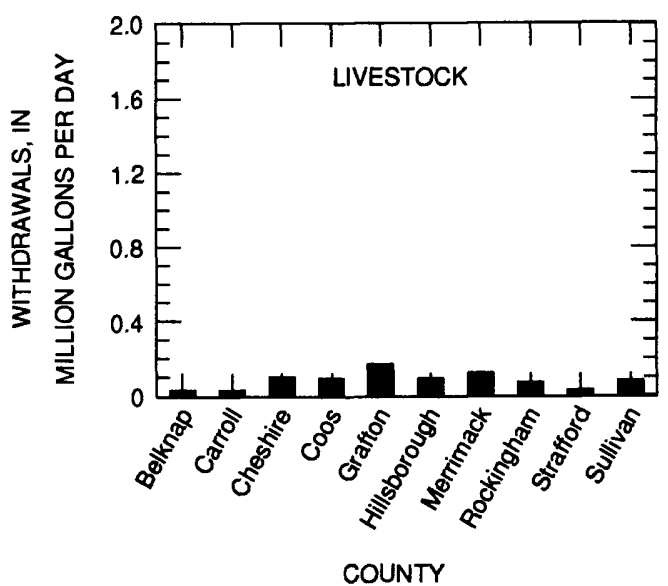

Figure 3. Water withdrawals in New Hampshire by category of use for counties, 1995.

[Note that the vertical scales are different for the upper four compared to the lower four charts] 
The percentage of total withdrawals that are unaccounted for varies among public suppliers, 10-15 percent is typical. Furthermore, unless a public supplier has an accurate and frequently calibrated metering system, it is difficult to derive reliable estimates of unaccounted-for water, especially if it is a system with older pipes prone to leakage.

\section{Domestic}

Domestic withdrawals totaled $32 \mathrm{Mgal} / \mathrm{d}$ and accounted for about 7 percent of total withdrawals. About 451,000 people, or 39 percent of New Hampshire's population, are self-supplied domestic users. These values are similar to those for 1990 , when domestic withdrawals were $27 \mathrm{Mgal} / \mathrm{d}$ for 415,000 people (Medalie and Horn, 1994).

The largest withdrawals for domestic use and the highest deliveries from public suppliers are in the Merrimack and Piscataqua-Salmon Falls River Basins (fig. 2b). Large values for domestic water withdrawals are seen in these river basins because they have large populations (table 1). River basins with the highest percentages of self-supplied population compared to total population are the Lower Androscoggin (100 percent) and Miller ( 86 percent). All river basins in New Hampshire are at least 22 percent self supplied

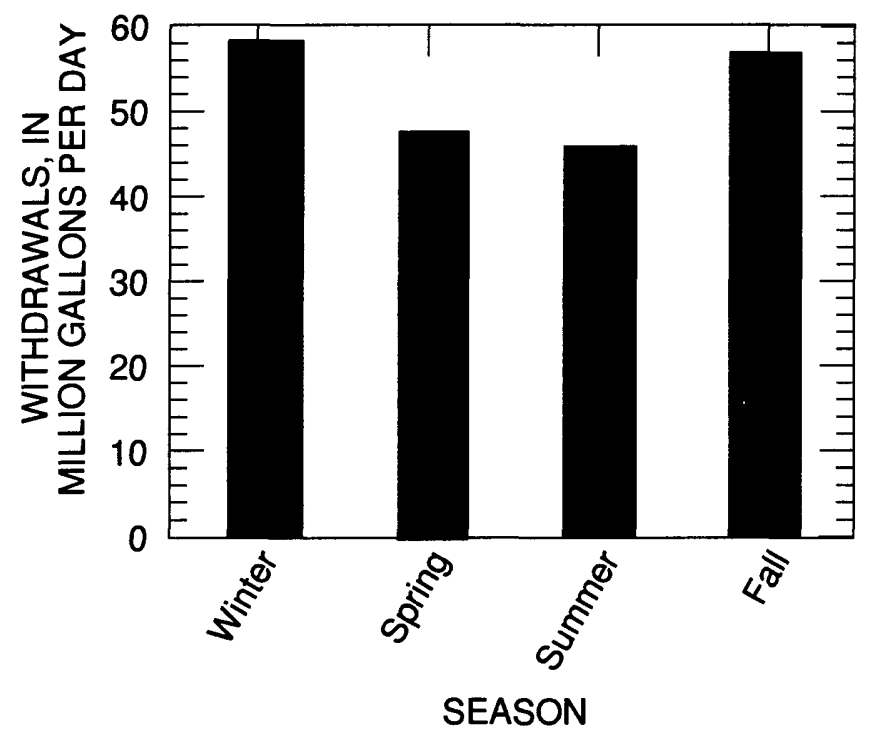

Figure 4. Seasonal commercial water withdrawals in New Hampshire, 1995. [Winter, January-February; spring, March-May; summer, June-October; fall, NovemberDecember] because of a substantial statewide rural population (U.S. Bureau of the Census, 1990).

Rockingham and Hillsborough Counties have the largest self-supplied domestic withdrawals (fig. 3b). Hillsborough and Rockingham Counties have the largest public-supplied deliveries. Among the counties in New Hampshire, Hillsborough County has the largest (73 percent) and Carroll County has the smallest (42 percent) percent of total population who are publicly supplied (divide population with public supply by population in table 1 ).

\section{Commercial}

Commercial withdrawals totaled $30 \mathrm{Mgal} / \mathrm{d}$ and accounted for about 7 percent of total withdrawals in New Hampshire. Withdrawals for commercial use in 1995 were $27.7 \mathrm{Mgal} / \mathrm{d}$ greater than the reported 1990 value of $2.3 \mathrm{Mgal} / \mathrm{d}$ (Medalie and Horn, 1994). The 1990 data did not include fish hatchery water use, which composed 58 percent of total commercial withdrawals in 1995. Snowmaking at ski areas accounted for 12 percent $(3.6 \mathrm{Mgal} / \mathrm{d})$ of commercial withdrawals in 1995. Other significant commercial users include hotels (and other lodging places), restaurants, personal services (laundries and car washes), and amusement and recreational services. About 80 percent of the data compiled for commercial use were site specific and 20 percent were estimated. Commercial withdrawals (fig. 2c) were largest in the Merrimack and the Pemigewasset River Basins. Public-supplied deliveries to commercial users were largest in the Merrimack River Basin. As seen in figure 3c, Hillsborough and Strafford Counties had the largest commercial withdrawals. Hillsborough County had the largest public-supplied deliveries. Snowmaking withdrawals were greatest in the Saco River Basin and Carroll County.

Seasonal commercial withdrawals computed as average daily use for the designated season are shown in figure 4. Withdrawals are largest during the winter (January and February, according to the classification in this report) and fall (November and December), and smallest during the summer (June through October). The two largest commercial uses of water, snowmaking and fish hatcheries, contribute towards this seasonal pattern. Water is used for snowmaking only during the winter and fall and sometimes also during March. Water 
use at fish hatcheries decreases during the summer as adult fish are removed from the hatchery to stock rivers and ponds.

\section{Industrial}

Industrial withdrawals totaled $43 \mathrm{Mgal} / \mathrm{d}$ and accounted for about 10 percent of total withdrawals in New Hampshire. In 1995, industrial withdrawals increased $5.6 \mathrm{Mgal} / \mathrm{d}$ from the 1990 reported withdrawals of $37.4 \mathrm{Mgal} / \mathrm{d}$ (Medalie and Horn, 1994). Industrial withdrawals (fig. $2 \mathrm{~d}$ ) were greatest in the Upper Androscoggin and the Upper Connecticut River Basins. About 93 percent of the data for industrial withdrawals were site-specific and 7 percent were estimated. Types of industries that use the most water in New Hampshire include paper, electrical equipment, chemicals, and machinery. Coos County has by far the largest self-supplied industrial water withdrawals (fig 3d). Public-supplied deliveries to industrial users were largest in the Merrimack River Basin and Hillsborough County.

\section{Thermoelectric Power}

Thermoelectric-power withdrawals in New Hampshire accounted for the largest use of water in the State, 51 percent $(230 \mathrm{Mgal} / \mathrm{d})$ of total withdrawals.

More than 99 percent of thermoelectric water use is at a fossil-fuel burning power facility in south-central New Hampshire, in the Merrimack River Basin (fig. 2e), Merrimack County (fig. 3e). The difference in reported water use between 1990 and 1995 for this facility accounts for the 10 percent decrease $(255 \mathrm{Mgal} / \mathrm{d})$ in total thermoelectric withdrawals from 1990 (Medalie and Horn, 1994). This facility has a once-through cooling system, whereby water is withdrawn, circulated in a non-contact chamber for cooling, and then returned directly into the Merrimack River. Thermoelectric power generating facilities that use freshwater in New Hampshire generated 3,870,000 kilowatt-hours of electricity during 1995. Facilities such as Seabrook Station and the Newington and Schiller generating plants, which use saline water, are not considered in this report.

\section{Mining}

Mining withdrawals totaled $7.0 \mathrm{Mgal} / \mathrm{d}$ and accounted for about 2 percent of total withdrawals in New Hampshire. Mining water use increased 4.2 Mgal/d from the 1990 estimate of $2.8 \mathrm{Mgal} / \mathrm{d}$ (Medalie and Horn, 1994), as the result of an increase in reported usage to the State Water User Registration Program. Most mining water withdrawals in New Hampshire were at sand and gravel facilities. At most mines in New Hampshire, water is pumped out of abandoned or active quarry holes for dewatering purposes and recycled for mining activities. Many mines have a settling pond on the premises to store and recycle water that is used for washing or sorting aggregate. River basins with the greatest volume of water used for mining (fig. 2f) are the Merrimack and Piscataqua-Salmon Falls. Counties with the greatest volume of water used for mining (fig. 3f) are Merrimack and Hillsborough. All water used for mining activities is assumed to be self supplied.

\section{Irrigation}

Irrigation withdrawals totaled $6.3 \mathrm{Mgal} / \mathrm{d}$ and accounted for about 1 percent of total withdrawals in New Hampshire. This volume is a significant increase from the 1990 reported irrigation withdrawals of 0.9 $\mathrm{Mgal} / \mathrm{d}$ (Medalie and Horn, 1994) mainly because golf course irrigation, accounting for about 70 percent of irrigation withdrawals in 1995, was not compiled with the 1990 data. River basins with the highest volume of water withdrawn for irrigation (fig. $2 \mathrm{~g}$ ) are the Merrimack and Piscataqua-Salmon Falls. Counties with the highest volume of water withdrawn for irrigation (fig. 3g) are Hillsborough and Rockingham. Vegetables and small fruit, primarily irrigated by overhead sprinklers, are the crops with the most acres irrigated (4,800 out of 5,750 acres) in New Hampshire, (Mitchell, 1995). During the growing season, and in the absence of rain, golf courses are intensively watered at tees, greens, and to a lesser extent, fairways. About 90 percent of irrigation withdrawals were assumed to be lost through evapotranspiration (C.E. Altemose, University of Vermont Cooperative Extension, Franklin County, oral commun., 1996) although the actual amount is affected by many factors such as climatological conditions, soil type, and crop type. 


\section{Livestock}

Withdrawals for livestock watering totaled $0.8 \mathrm{Mgal} / \mathrm{d}$ and accounted for less than 1 percent of total withdrawals in New Hampshire. Withdrawals for livestock use in $1995 \mathrm{declined} 0.2 \mathrm{Mgal} / \mathrm{d}$ from reported the livestock withdrawals in 1990 of $1.0 \mathrm{Mgal} / \mathrm{d}$ (Medalie and Horn, 1994). As seen in figure 2h, the largest withdrawals are found in the Merrimack and the Upper Connecticut-Mascoma River Basins. Grafton and Merrimack Counties have the largest withdrawals (fig. 3h) for livestock. Livestock withdrawals were estimated as 75 percent from ground water $(0.6 \mathrm{Mgal} / \mathrm{d})$ and 25 percent from surface water $(0.2 \mathrm{Mgal} / \mathrm{d})$. Water used for dairy cattle feeding and washing accounted for the largest volume of livestock water use. Some of the animals included in the livestock water-use analysis are horses, beef cattle, sheep, and swine. All livestock use is assumed to be self-supplied in conformity with guidelines developed for the USGS national water-use compilation.

\section{Summary of Withdrawals and Use}

Water withdrawals totaled about $450 \mathrm{Mgal} / \mathrm{d}$ in 1995. This value represents a 7 percent increase from 1990 total withdrawals of $422 \mathrm{Mgal} / \mathrm{d}$ (Medalie and

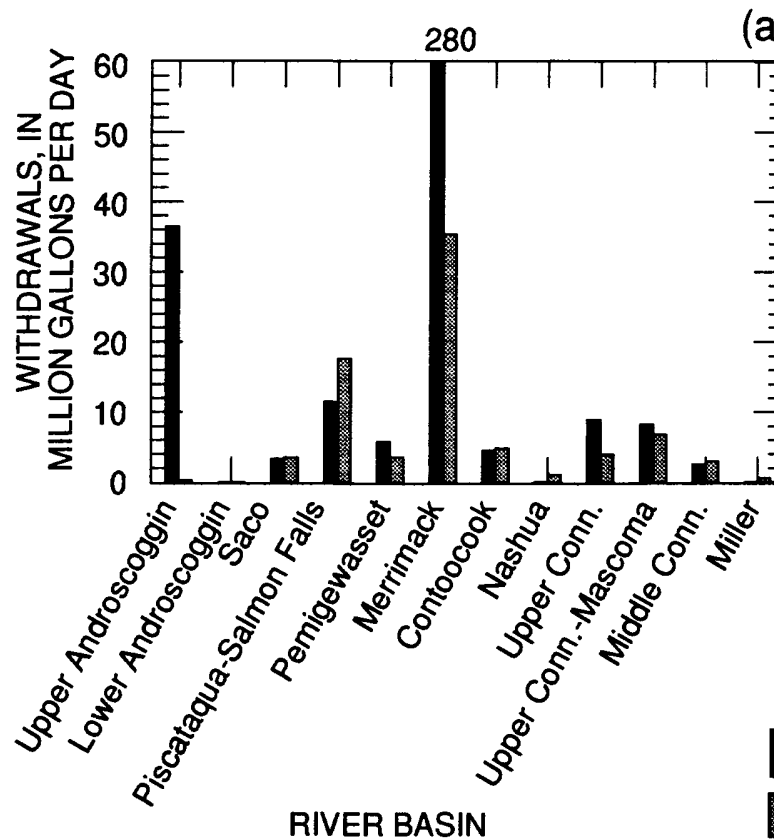

(a)

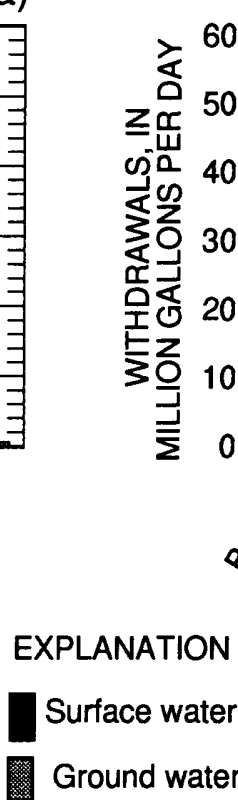

Horn, 1994), primarily because of increased reported commercial withdrawals. Total withdrawals (fig. 5a) were highest in the Merrimack River Basin, followed by the Upper Androscoggin and the Piscataqua-Salmon Falls River Basins. Counties with the largest withdrawal volumes (fig. 5b) were Merrimack, Hillsborough, and Coos.

Public suppliers do not really "use" the water they withdraw, but rather they distribute it to various users. Thus, there is a difference between withdrawals and use that should be defined in order to best represent water demands in the State. Total water use for any individual category is the sum of self-supplied withdrawals by water users and deliveries by public suppliers to users in that category. In 1995, total water use in New Hampshire (fig. 6), averaging $450 \mathrm{Mgal} / \mathrm{d}$, was dominated by thermoelectric power $(230 \mathrm{Mgal} / \mathrm{d}, 51$ percent). The second and third largest categories of use were domestic ( $89 \mathrm{Mgal} / \mathrm{d}, 20$ percent) and industrial (56 Mgal/d, 13 percent). The category, unaccounted-for water, accounts for 2 percent of total water use

$(6.7 \mathrm{Mgal} / \mathrm{d})$, a larger percentage than the categories of irrigation or livestock (fig. 6).

Total per capita water use is calculated as total water use divided by total population for a river basin or county (last column, table 1). Since domestic selfsupplied water use is estimated at 70 gallons per person

Figure 5. Total surface-water and ground-water withdrawals in New Hampshire by (a) river basin and (b) county, 1995. [Conn., Connecticut] 
per day and public-supplied water use at 82 gallons per person per day, a total per capita water-use value greater than 82 indicates the presence of either significant water uses besides household use or large unaccounted-for uses (such as imports or exports). The Upper Androscoggin River Basin has high per capita water use because industrial and commercial use is high and population is low. The Merrimack River Basin has high per capita water use because of large withdrawals for thermoelectric use. Coos and Merrimack Counties have high per capita water-use values for the same reasons as the Upper Androscoggin and Merrimack River Basins, respectively.

\section{SURFACE-WATER AND GROUND-WATER WITHDRAWALS}

Withdrawal data organized by source is useful because there are numerous differences in availability, treatment, protection issues, and geographic

distribution between surface and ground water. About $370 \mathrm{Mgal} / \mathrm{d}$ (82 percent) of total water withdrawals in the State are from surface-water sources and $82 \mathrm{Mgal} / \mathrm{d}$ (18 percent) are from ground-water sources. These percentages are similar to those for 1990, when surface water accounted for 85 percent and ground water for 15 percent of water withdrawals (Medalie and Horn, 1994). As seen in figure 7, the largest volume of surface-water withdrawals, $230 \mathrm{Mgal} / \mathrm{d}$ ( 62 percent), is for thermoelectric-power use, followed by public supply, $66 \mathrm{Mgal} / \mathrm{d}$ (18 percent). Public supply and domestic each accounts for $31 \mathrm{Mgal} / \mathrm{d}$, or 38 percent of ground-water withdrawals.

Most surface-water withdrawals were in the Merrimack (280 Mgal/d) and the Upper Androscoggin (37 Mgal/d) River Basins (fig. 5a). Most ground-water withdrawals were in the Merrimack (36 Mgal/d) and the Piscataqua-Salmon Falls (18 Mgal/d) River Basins. Merrimack County had the largest volume of surfacewater withdrawals $(240 \mathrm{Mgal} / \mathrm{d})$, followed by Coos (43 Mgal/d) County (fig. 5b). Ground-water withdrawals were greatest in Hillsborough County (21 Mgal/d) and Rockingham County (19 Mgal/d).

\section{HYDROELECTRIC-POWER USE}

In 1995, hydroelectric-power instream use totaled $33,000 \mathrm{Mgal} / \mathrm{d}$ in New Hampshire (table 2), compared to $46,000 \mathrm{Mgal} / \mathrm{d}$ in 1990 (Medalie and Horn, 1994).

This difference is explained by differences in hydrologic conditions between the two years.

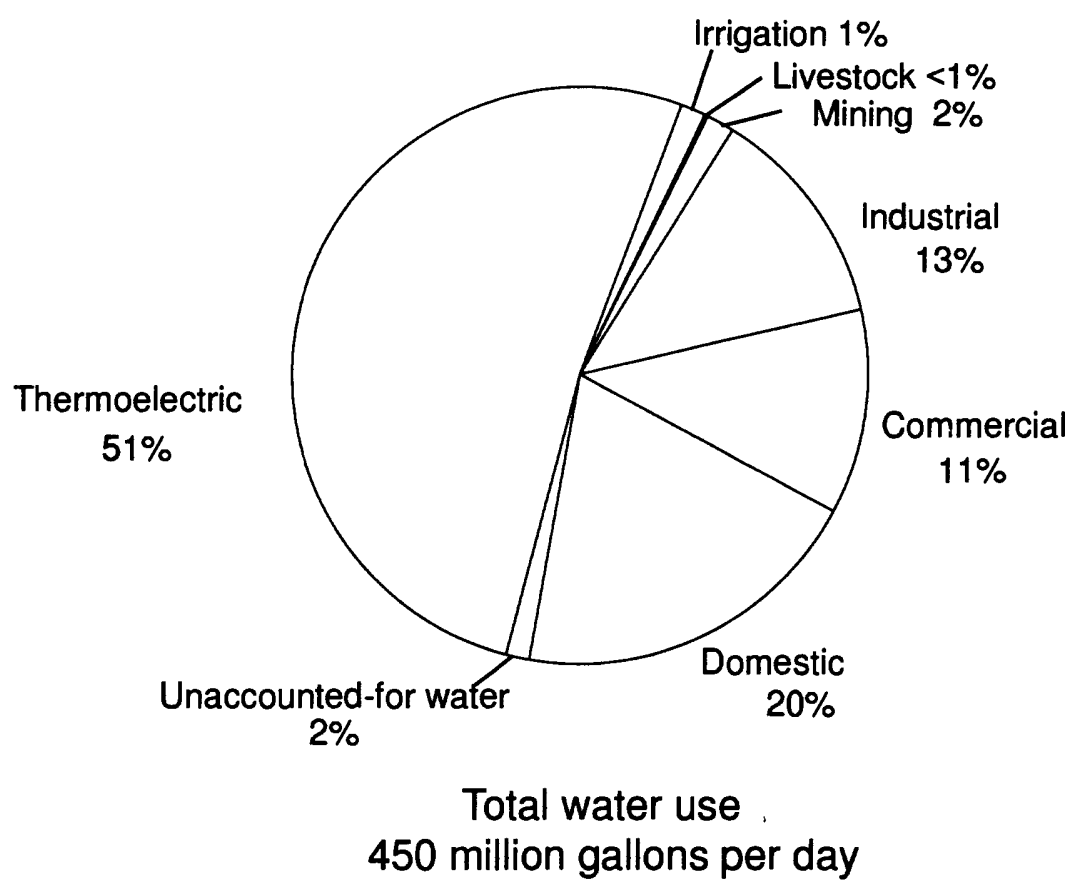

Figure 6. Percentage of total water use in New Hampshire, by category of use, 1995. 


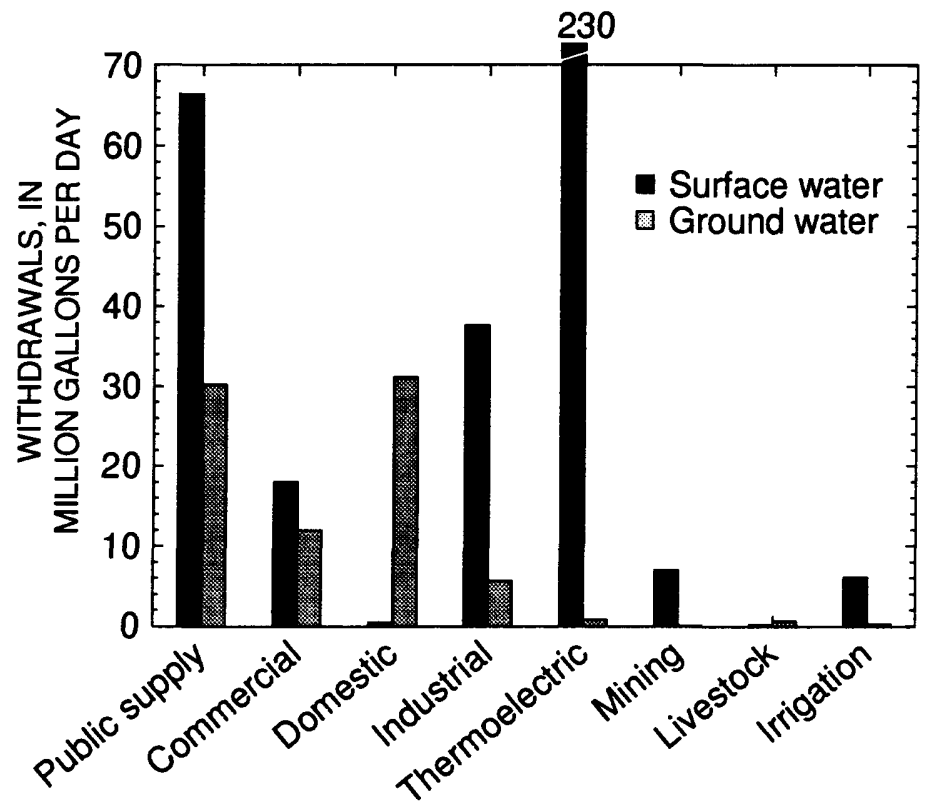

\section{CATEGORY OF USE}

Figure 7. Surface- and ground-water withdrawals in New Hampshire, by category of use, 1995.

Streamflow statewide was above normal for 7 months in 1990 (Toppin and others, 1991, 1992) and above normal for only 3 months in 1995 (Hammond and others, 1996; Coakley and others, 1997). Water for hydroelectric-power generation is generally used directly in the river. Because water is usually not withdrawn for use offsite, hydroelectric-power use is not grouped with the other categories described in this report. In addition to hydroelectric-power use, there are many other instream uses of water, including fish and other biological habitat, wastewater assimilation, boating, rafting, and swimming, none of which were estimated as part of this study. River basins with the highest hydroelectric-power use are the Upper Androscoggin and the Upper Connecticut-Mascoma. Counties with the highest hydroelectric-power use are Coos and Sullivan. Hydroelectric-power use generated approximately $1,460,000$ kilowatt-hours of electricity during 1995.

\section{SUMMARY}

Selected data from the 1995 USGS water-use compilation for New Hampshire were presented in this report, compiled by river basin and county. Water withdrawals totaled about $450 \mathrm{Mgal} / \mathrm{d}$ in 1995 . Thermoelectric-power withdrawals accounted for 51 percent of all withdrawals in New Hampshire; publicsupply withdrawals for 22 percent; self-supplied withdrawals for industrial use, 10 percent; commercial, 7 percent; domestic, 7 percent; mining, 2 percent; irrigation, 1 percent; and livestock, less than 1 percent. Total withdrawals were highest in the Merrimack and the Upper Androscoggin River Basins, and in Merrimack and Hillsborough Counties. About 82 percent of total water withdrawals in the State are from surface-water sources and 18 percent are from groundwater sources. Total water use for any individual category is the sum of withdrawals by water users and deliveries by public suppliers for users in that category. Hydroelectric instream use was about $33,000 \mathrm{Mgal} / \mathrm{d}$ in 1995.

\section{REFERENCES}

Coakley, M.F., Keirstead, Chandlee, Brown, R.O., and Hilgendorf, G.S., 1997, Water resources data, New Hampshire and Vermont, water year 1996: U.S. Geological Survey Water-Data Report NH-VT-96-1, 189 p.

Davis, W.Y., Rodrigo, D.M., Opitz, E.M., Dziegielewski, B., Baumann, D.D., and Boland, J.J., 1991, IWR-MAIN water use forecasting system - version 5.1 - user's manual and system description: U.S. Army Corps of Engineers, Institute for Water Resources, Report 88-R6, $307 \mathrm{p}$.

Hammond, R.E., Coakley, M.F., Kierstead, C., and Kiah, R.G., 1996, Water resources data, New Hampshire and Vermont, water year 1995: U.S. Geological Survey Water-Data Report NH-VT-95-1, 205 p.

Medalie, Laura and Horn, M.A., 1994, Estimated withdrawals and use of freshwater in New Hampshire, 1990, U.S. Geological Survey Water Resources Investigations Report 93-4096, 1 pl.

Mitchell, J.R., 1995, New Hampshire section: 1995 irrigation survey: Irrigation Journal, 46(1), p. 32.

Seaber, P.R., Kapinos, F.P., and Knapp, G.L., 1987, Hydrologic unit maps: U.S. Geological Survey Water-Supply Paper 2294, 63 p.

Toppin, K.W., McKenna, K.E., Cotton, J.E., and Denner, J.C., 1991, Water resources data, New Hampshire and Vermont, water year 1990: U.S. Geological Survey WaterData Report NH-VT-90-1, $136 \mathrm{p}$.

1992, Water resources data, New Hampshire and Vermont, water year 1991: U.S. Geological Survey WaterData Report NH-VT-91-1, 158 p. 
U.S. Bureau of the Census, 1990, STF3A data from the internet: http://venus.census.gov/cdrom/lookup/CMD=LIST/DB=C90STF3A/L $\mathrm{EV}=\mathrm{STATE}$.

U.S. Department of Commerce, 1994, 1992 Census of Agriculture, volume 1, geographic area series-part $29 \mathrm{New}$ Hampshire State and County Data: Washington D.C., Bureau of the Census, AC92-A-29, 216 p.

\section{GLOSSARY:}

\section{Water-use categories:}

Commercial: use of water in commercial facilities, such as hotels, restaurants, office buildings, hospitals, or schools. Water withdrawn by fish hatcheries and by snowmaking facilities at ski resorts is also included.

Domestic: use of water for household purposes, including water used indoors, such as for drinking and bathing, and outdoors, such as for lawn watering and car washing.

Hydroelectric-power: water used in the generation of electricity at plants where the turbine generators are driven by moving water.

Industrial: use of water in fabricating, processing, washing, and cooling industrial materials.

Irrigation: use of water for irrigation of crops and selfsupplied water for golf courses.

Livestock: use of water for watering of livestock and horses.

Mining: use of water in the extraction of minerals, which includes withdrawals associated with quarrying, milling, gravel washing, or dust control. Withdrawals associated with dewatering are included only if the water is used for another mining-related activity.
Thermoelectric power: use of water in the process of generating power from fossil-fuel or nuclear sources. The water is used primarily for cooling.

\section{Other terms:}

Evapotranspiration: water evaporated from soil or plant surfaces or transpired (taken up internally by plants and returned to the atmosphere as part of plant metabolism).

Fish hatchery water use: water used for raising fish for later release, used in association with the operation of fish hatcheries or fishing preserves.

Per capita water use: The average volume of water used per person during a standard time period, generally per day.

Public-supply deliveries: Water delivered to a user or group of users through public-supply system distribution lines.

Public-supply withdrawal: water withdrawn by public and private water suppliers who provide water to domestic, commercial, industrial, and other users. Public supply also includes public use, losses, and water transfers to other public suppliers or basins.

Self-supplied withdrawal: Ground-water or surface-water withdrawn by a user and not obtained from a public supplier.

Unaccounted-for water: Water supplied from a public water supply that has not been accounted for as being distributed to domestic, commercial, industrial, or thermoelectric-power users. It includes public water use (firefighting, street washing, and municipal parks and swimming pools), leakage (conveyance loss), and meter errors. 